\title{
GRøNLANDS APOSTEL I KAMPEN MOD ABRAHAM GRØNLAENDER - OFRINGSNARRATIVER I KIM LEINES ROMAN RØD MAND/SORT MAND
}

\author{
ANITA SOÓS
}

\begin{abstract}
Greenland's Apostle in The Fight Against Abraham Greenlands Sacrification Narratives in Kim Leine's Novel Red Man / Black Man The literary interest in Greenland has been growing steadily in recent years. Both the question of the country's secession from Denmark and the handling of imperialism's historical heritage have occupied the public. The author Kim Leine diligently contributes to the debate with his works on the cultural encounters between Danes and Greenlanders. Following an overview of Leine's description of the coexistence of colonizers and colonized and the political and religious influence of the former on the latter in the beginning of the 18. century this paper discusses how Leine tries to debunk the common perception of Danes as soft colonizers. The main purpose of the article is to investigate how the difference between the two cultures manifests itself in the father-son relations, with a special focus on the interpretation of the act of sacrifice in the biblical story of Abraham and Isaac. The approach is inspired by postcolonial theory.
\end{abstract}

Keywords: Danish literature, cultural encounters, Kim Leine, offering, fathers and sons

\section{Introduktion}

Den litterære interesse for Grønland vokser støt. Det sker i kølvandet på den især i begyndelsen af 2010erne heftige, men stadig aktuelle politiske diskussion. Både spørgsmålet om landets løsrivelse fra Danmark og håndteringen af imperialismens historiske arv har optaget offentligheden i de seneste år.

Forfatteren Kim Leine bidrager flittigt til debatten om Grønland. Med sine værker, hvor mødet mellem det danske og det grønlandske står i fokus, gør han umisforståeligt rede for sit ståsted og i dedikationen af romanen Profeterne i Evighedsfjorden fra 2012 formulerer han også eksplicit sin sympati for Grønlands uafhængighed. I anden (men kronologisk set første) del af sin planlagte Grønlands-trilogi, Rød mand/sort mand beskriver han de første møder og konfrontationer mellem de kristne kolonisatorer og de hedenske indfødte, og tegner ikke et ligefrem flatterende billede af førstnævnte. Ved at undersøge sameksistensen og den gensidige påvirkning kolonisatorer og koloniserede imellem, samt 
ved at udøve kritik af det opståede under- og overlegenhedsforhold, skriver romanerne sig ind i den dansk-grønlandske antikolonialistiske litteratur ${ }^{1}$, og forsøger at afsløre falsummet i den gængse opfattelse af danskere som bløde kolonisatorer.

Kirsten Thisted retter i sine overvejelser omkring den første roman i Kim Leines trilogi opmærksomheden på, at den er blevet kritiseret "for at give et fordrejet billede af Danmarks fremfærd i Grønland" (Thisted 105). Denne kritik kan på samme måde formuleres i forbindelse med Rød mand/sort mand, hvis man accepterer de udbredte narrativer om den dansk-grønlandske historie. Men Thisted kræver med god ret et mere nuanceret billede og argumenterer for en nytænkning af den herskende opfattelse af dansk kolonialisme i Grønland. Samtidigt fremhæver hun fortidens relevans med hensyn til den historiske udvikling og landets fremtid. Den historiske fiktion tager uden tvivl stilling til den aktuelle politiske debat og kaster et kritisk lys på den forestilling af den grønlandske kultur, der er blevet skabt for at styrke danskernes magt over deres tidligere koloni ${ }^{2}$.

I romanen går den økonomisk-politiske underkastelse af de indfødte hånd i hånd med deres omvendelse og kristningen bygger på koloniherrernes selvbestaltede religiøse overlegenhedsfølelse. På trods af en vis interesse og tilsyneladende accept fra grønlændernes side fører situationen til uforsonlige modsætninger. Disse kan kun ophæves ved de underkastedes frigørelse, i romanens optik ved bevarelse af deres (religiøse) uafhængighed eller finden frem til en særlig form for kristendom. Konfrontationerne mellem de to uforenelige kulturer bliver håndgribelige bl.a. i diskussionerne mellem den hedenske åndemaner Aappaluttoq og den lutheranske missionær Hans Egede, og illustreres også ved deres kamp om den førstes søn, som præsten, som følge af sin misforståede tolkning af begrebet Guds gave, har taget til sig og opdraget i den kristne tro. Deres indædte kamp løber som en rød tråd gennem hele fortællingen og når sit højdepunkt i deres fortolkning af den bibelske historie om Abraham og Isak, hvis vigtighed understreges af selve forfatteren, som ved at citere Kierkegaards poetiske bearbejdelse af stoffet i Frygt og Baven (1843) allerede med den ene motto i begyndelsen af bogen retter læserens opmærksomhed på fader og søn forholdet.

I det følgende undersøges, hvordan mødet mellem de to kulturer manifesterer sig i fader-søn relationerne med særlig vægt på trekanten Aappaluttoq, Hans Egede og Paa$\mathrm{pa} /$ Frederik Christian, men for at nuancere billedet inddrages også andre fader-søn-relationer. Læsningen er inspireret af postkolonialistiske synspunkter og af Edward Saids kulturmødeteori, samt hans udtalelser vedrørende (u)muligheden af mødet mellem den

1 I den postkoloniale tid er der blevet skrevet flere værker, hvis forfattere har et kritisk syn på Danmarks kolonisering af Grønland og det narrativ og den diskurs, der var kolonialiseringens. Værkerne er i reglen skrevet med sympati og kærlighed om livet i Grønland. Og med en omfortolkning af de koloniale værdier og hierarkier. Ud over Kim Leine er Jørn Riels skrøner og Peter Høegs grønlandske karakterer med til at nuancere og nedbryde de eksisterende stereotypier, som fx skildrer grønlænderne som primitivt naturfolk eller senere som fangere og gode kristne. I sin artikel Gennem mine årer fosser fjeldenes store elve giver Mathias Nielsen en diakronisk beskrivelse af ændringer i danskernes forestillinger om grønlændere, samt ændringer i grønlændernes selvopfattelse fra 1700-tallet op til i dag (Nielsen 7).

2 Slg. E. Said, der har i tråd med den postkoloniale optik i et interview med C. Burgmer (Said 1998, 24) omkring asymmetriske kulturmøder påpeget, at forestillingen om en bestemt kultur eller civilisation bliver skabt med hensyn til opnåelse af visse mål, bl.a. opretholdelse af bestemte magtstrukturer. 
vestlige kultur ('os') og Orienten ('den anden') ${ }^{3}$. Men sigtet for herværende artikel er ikke uddybning af den postkoloniale tilgang i litterære læsninger. I tekstnære nedslag vil artiklen præsentere forskellige aspekter ved mødet mellem de to kulturer. Der lægges særlig vægt på det religiøse felt. Igennem teologiske tolkninger af den bibelske historie om Abraham og Isak, vil jeg redegøre for, hvordan historien anvendes til at illustrere forskelle mellem den danske og den grønlandske kultur.

\section{Kulturmøde og kulturchok}

Kolonialiseringen af Grønland begyndte i 1721, da den norskfødte præst Hans Egede sejlede med store forhåbninger til det fjerntliggende område. Oprindeligt drømte han om at reetablere kontakten mellem Danmark (Skandinavien) og de gamle nordboer på øen, som han gerne ville gøre bekendt med den lutheranske tro. Men da han kun fandt deres forladte bygder, måtte han affinde sig med skuffelsen og slå sig til tåls med at kristne de hedenske indfødte ${ }^{4}$. Det er denne historiske situation, som danner baggrund for Kim Leines fortælling, som med sin antikolonialistiske tilgangsvinkel ikke nødvendigvis er en objektiv, historisk set pålidelig skildring, men fiktion ${ }^{5}$. En fiktion, som på mange måder prøver at nedbryde de udbredte stereotypier om Grønland og landets indfødte befolkning, så som forestillingen om et primitivt folk, som er nært knyttet til naturen og lever i et harmonisk fællesskab, men på grund af sit lave økonomiske, åndelige og kulturelle udviklingstrin vil nyde godt af de mere udviklede danske kolonisatorers og de kristne missionærers virksomhed.

Ved konstant at henvise til grønlændernes primitivitet og ukultiverethed sætter danskerne sig i alle henseender over de indfødte og føler sig kaldet til at påtvinge dem deres egen civilisation, som dog i mange situationer afsløres som utilstrækkelig. Koloniseringen og indførelsen af kristendommen kobles sammen og det er den kristne religion, som Egede og hans to unge missionærkolleger anvender til at overbevise de indfødte om kolonisatorernes overlegenhed: missioneringstanken forvandles til undertrykkelsesretorik. Egede har altid sine moralske læresætninger parat fra den lutherske katekismus til at understøtte sin ide om at protestantismen ikke bare er vejen til frelsen, men også et afgørende middel i de indfødtes menneskelige frigørelse. Religionen er en konstruktion, der kan etableres og opretholdes ved hans ihærdige omvendelsesbestræbelser, som først og fremmest bygger på tugtelse og terperi.

3 "The Orient is not only adjacent to Europe; it is also the place of Europe's greatest and oldest colonies, the source of its civilizations and languages, its cultural contestant, and one of its deepest and most recurring images of the Other." (Said 1979, 1).

4 Herfra navnet Grønlands apostel, som Hans Egede fik for sin rolle som missionær og præst i Grønland.

5 Det betyder ikke at den antikolonialistiske tilgang udelukker den historiske objektivitet, men at den er med til at formidle en bestemt opfattelse og fortolkning af de historiske begivenheder og - som Gábor Csúr i sin PhD-afhandling gør opmærksom på - kan være med til at tegne et bestemt billede af nutidens politiske atmosfære (Csúr 43-45). I den historiske fortælling fokuseres der på Hans Egedes missionsvirksomhed, som i den officielle historieskrivning fremstår som noget positivt, men når Leine beskriver missionærens karakter, digter han videre på hans virke og det er de ikke ligefrem sympatiske karaktertræk, der rykker i forgrunden. På den måde resulterer fiktionaliseringen i, at der stilles spørgsmålstegn ved hele hans foretagende. 
Men hvad er det for en kristendom, den danske missionær repræsenterer? Egede forkynder en meget streng dogmatisk protestantisme, holder fast ved Biblens autoritet og finder svar på alle sine spørgsmål hos Luther. Hans religiøsitet bygger på en ubetinget lydighed over for Gud, og derfor er det heller ikke overraskende, at han i hele sit liv viser en lidenskabelig interesse for den bibelske fortælling om Abraham og Isak. I sit gudsforhold tåler han ingen slaphed, ingen modsigelse eller udenomssnak. I denne henseende er han lige så skrap over for sig selv, som over for sine danske og grønlandske omgivelser. Som Guds trofaste og lydige tjener, påtager han sig opgaven at kristne den hedenske befolkning, som han ellers foragter. Han går ubøjeligt til værks, selv om han er overbevist om, at grønlænderne endnu ikke er modne til at modtage det kristne budskab. Han beskriver dem som et ukultiveret naturfolk, som skal underkastes. Til sine to unge kolleger foreslår han at gå frem med fast hånd og hvis det er nødvendigt, viger han ikke tilbage fra vold:

Ingen frygt. Ingen blødhed. Ingen nåde. De skal tugtes. De er koldblodige som kakerlakker. Men de lader sig let kue. Brug pisken hvis det er nødvendigt. Eller vift bare om næsen med den. Det er som regel nok. [...] De er jo dog også en slags Guds skabninger og har en naturlig tilbøjelighed mod frelse som alle andre selv om den ligger dybt begravet under spækket. Og lige så snart man forlader dem, glemmer de alt hvad man har sagt, og hengiver sig til deres uglspil og liderlighed (Leine 2018, 73).

Egedes Grønlandsbillede er en bekræftelse på den koloniale diskurs, som Aappaluttoqs modfortælling stilles op mod. Den grønlandske åndemaner er godt klar over, at de kristne missionsforsøg ikke fører til de infødtes integration, men til deres religiøse og politiske undertrykkelse, derfor udløser de stærk modstand hos ham og intuitivt også hos hans folk. Egede tager slet ikke hensyn til de indfødtes indstilling, og ved den hårdnakkede forkyndelse af protestantismen vil han helt fortrænge deres oprindelige tro. Grønlænderne viser en stærk modvilje over for ham, afviser hans fremgangsmåde og forsøger i en vis grad at holde fast ved deres religiøse identitet. I mødet med det fremmede kan de slet ikke indse deres underlegenhed, som den arrogante danske missionspolitik er et udtryk for, og på grund af de danske kolonisatorers livsførelse og hykleriske religiøsitet føler de sig ikke mindreværdige, derfor modsætter de sig Egedes bestræbelser og skaber deres egen kristendom, som er en særlig kombination af den kristne og den hedenske tro. De overtager kun de elementer, der tilfredsstiller deres aktuelle behov og hjælper med at overvinde deres håndgribelige og til tider uforklarlige frygt. Det, at de blander de to former for religiøsitet, kan opfattes som tegn på deres modstand og i en vis forstand også som et svagt og ubevidst forsøg på at bevare deres selvidentitet og uafhængighed. Det kommer eksplicit til udtryk i Aappaluttoqs overvejelser omkring kristendommen, frelsen og Jesu figur. Han ved, at kristningen af landet kan være dets redning, men er også klar over, hvad der kan mistes. Bevidst om sit værd vil han hævde sig over for Egede og i form af en betragtelig udvidelse af perspektivet for gensidig forståelse og befrugtende sameksistens af kristendom og hedenskab tilbyder han grønlænderne en reel mulighed for, at de ikke skal opgive sig selv: 
Disse ting kan godt findes side om side med troen på Gud og Jesus, både Sassuma arnaa, Tornaarsuk og Sila og alle de andre [...] Jeg kunne indføre kristendommen her i landet så nemt som ingenting hvis jeg fik lov til at gøre det på min måde. [...] Men præsten Egede fatter ikke det her. Derfor må vi være uvenner og fjender (Leine 2018, 74).

Ved at ophæve de anerkendte magtforhold og ved at foreslå en praktisk kristendom vender Aappaluttoq sig ikke mod kristianiseringen af landet, men mod den måde, den udføres på i praksis. Når det kommer til stykket, opfatter han ikke den grønlandske og den danske kultur som to adskilte størrelser, der aldrig skulle kunne mødes. Han vil gerne overskride grænserne og, på trods af de mange fejlslagne og modstridende intentioner, åbne nye veje for udviklingen.

Eftersom Egede helt lukker af for at få en dybere indsigt i den grønlandske tro, er han ikke i stand til at acceptere Aappaluttoqs særlige form for religiøsitet. Af samme grund kan de danske missionsforsøg heller ikke give det ønskede resultat. De indfødtes utraditionelle kristendom kan opfattes som konkretisering af bevarelsen til en vis grad af deres uafhængighed ${ }^{6}$.

Den grønlandske åndemaner giver flere steder i romanen udtryk for, at nøglen til landets succesfulde kristianisering er en gensidig accept af og forståelse for hinandens kultur. I denne henseende byder romanens epilog på en løsning, når der berettes om ankomsten af den nye præst Lauritz Oxbøl, som skal oprette en ny koloni i Holsteinsborg. Som Titias og Aappaluttoqs søn kunne han være den rigtige til at formidle mellem den danske og den grønlandske kultur, men i stedet for at have en befrugtende dobbeltidentitet, repræsenterer han danskheden. Han kender slet ikke sine rødder, det er kun læseren, Titia og Aappaluttoq, der har kendskab til hans oprindelse. Han holder sine adoptivforældre, Sise og Johan, for sine forældre og føler en stærk tilknytning til den danske pastor Oxbøl, som stod for hans opdragelse i Danmark, hvilket også udtrykkes ved at han ændrer sit navn.

Det er formentlig forklaringen på at hans missionsforsøg er tvetydige og mislykkes, hvilket læseren kender fra trilogiens tredje del, hvor man også præsenteres for den grønlandske kateket Bertel, som i slutningen af romanen fremstår som den rigtige formidlerfigur i kolonisatorernes og de koloniseredes religiøse kamp. Som en "tam vildmand" er han en slags afløser for den utæmmede åndemaner i Rød mand/sort mand, som ser klart, men endnu ikke kan realisere sine ideer. I slutningen af romanen vinker han forsonende farvel til Egede og viger samtidig pladsen til sine efterfølgere; i første omgang Lauritz, som ikke kan leve op til forventningerne. Der er lang vej fra Aappaluttoq til Bertel. Lang vej til, at det forsoningspotentiale, som Bertel gennem bevarelsen af sin grøndlandske identitet og ved hjælp af sin tilpasningsevne til den protestantiske kirkes institutionelle indretning bærer, kan blive til virkelighed:

Farvel, præst. Du tror det er slut nu. Du tror at kampen er forbi. Sådan er det for jer danskere. For jer er Grønland noget med en begyndelse og en slutning, noget man rejser til og forlader igen. Men sådan er det ikke for os der hører til her. For os slutter det aldrig. Grøn-

6 I Rød mand/sort mand er den specielle form for religiøsitet udtryk for de indfødtes passive modstand mod koloniseringen, mens den religiøse bevægelse og det af Habakuk og Maria Magdalena stiftede kristne fællesskab i trilogiens tredje del Profeterne i Evighedsfjorden to generationer senere repræsenterer et aktivt løsrivelsesforsøg fra den danske kolonimagt. 
land er vores land, hele vores liv fra vugge til grav. For os er kampen ikke forbi. Den er knap nok begyndt (Leine 2018, 502).

\section{Tag Isak, din eneste søn, ham, du elsker og bring ham som brændoffer}

Romanen Rød mand/sort mand byder på flere forsoningsmuligheder i konfrontationerne mellem de to kulturer, men viser samtidigt også, hvordan de strander på grund af deres forskellighed, som bl.a. anskueliggøres gennem de enkelte personers holdning til fortællingen om Abraham og Isak og den mangfoldige bearbejdelse af fader-søn-forholdet. Men inden jeg går nærmere ind på det, kan det være relevant at begynde med en kort udredning af den bibelske fortælling og ofringens ritual.

Abraham og Isaks historie lægger op til flere læsninger. I sin roman henviser Kim Leine til Søren Kierkegaard, hvis fiktive forfatter, Johannes de silentio præsenterer fire alternativer af den såk. akeda i Frygt og Bæeven, hvor han undersøger, hvordan den enkelte kan forholde sig til det absolutte og forsøger at formulere det usigelige med udgangspunkt i Abrahams tavshed. I de forskellige variationer af historien lægger han vægt på forskellige aspekter i forholdet mellem Gud og mennesket (Abraham) og forholdet mellem far og søn (Abraham og Isak). I den første version fokuseres der på, at Abraham er nødt til at forstille sig og lyve for sin søn, fordi han er overbevist om, at den eneste vej til at Isak ikke mister sin tro på Gud er ved at vise sig ubarmhjertig og nådesløs. Det er den anden fortælling, der er tættest på den bibelske beretning, men bliver ikke stående ved Guds jordiske velsignelse efter ofringen af vædderen. I den bliver Abraham en resigneret, dybt skuffet gammel mand efter prøvelsen. Den tredje parafrase fokuserer på, at Abraham gør sig skyldig i etisk forstand, i det han er parat til at ofre sin søn, og stiller sig selv spørgsmålet om, hvordan Gud kunne tilgive ham. Den fjerde version leger med muligheden for, at Abraham modsætter sig Guds befaling og ikke vil dræbe Isak, som til gengæld er klar over, hvad hans far havde i sinde.

I Kierkegaards læsning kan det, at Abraham underkastes en prøve på det hårdeste, dvs. at Gud kræver af ham, at han ofrer sin dyrebarste skat Isak, opfattes som en prøvelse af troen. Og Abraham er som troens ridder urokkelig i sin tro. Han er parat til at dræbe sin søn, fordi han også tror på, at Gud er i stand til at genopvække ham ${ }^{7}$. Kirkefædrenes skrifter ${ }^{8}$ gør imidlertid opmærksom på, at Abraham godt var klar over, at hans historie

7 slg. "Men hvad gjorde Abraham; Han kom hverken for tidlig eller for sildig. Han besteg Æslet, han reed langsom hen ad Veien. I al den Tid troede han; han troede, at Gud ikke vilde fordre Isaak af ham, medens han dog var villig til at offre ham, naar det forlangtes. Han troede i Kraft af det Absurde; thi menneskelig Beregning kunde der ikke være Tale om, og det var jo det Absurde, at Gud, som fordrede det af ham, i næste Øieblik skulde tilbagekalde Fordringen. [...] Lad os gaae videre. Vi lade Isaak virkelig blive offret. Abraham troede. Han troede ikke, at han engang skulde blive salig hisset, men at han skulde blive lyksalig her i Verden. Gud kunne give ham en ny Isaak, kalde den offrede tillive" (Kierkegaard 131).

8 En af de første kristne fortolkere af 1 Mosebog 22 var den alexandrinske kirkefader Origenes (ca. 185-254). Han behandler ofringen af Isak i to af sine homilier over Genesis (8. og 9. homili). Ved at forbinde ofringen med Jesu korsfæstelse og ved at henvise til forskellige skriftsteder (fx Heb 11,17) i det Nye Testamente argumenterer han i sin ottende homili for, at Abraham godt vidste, at Gud var 
forudgriber Jesu død og genopstandelse i det Nye Testamente, hvilket stiller hans offer i en frelseshistorisk dimension.

I Rød mand/sort mand finder vi en blanding af de ovenstående opfattelser. Den bibelske beretning spiller både for Egede og Aappaluttoq en central rolle, de har hver deres dynamiske udlægning af ofringen. Mens Egede har en fast forestilling om, at historien handler om Abrahams ubetingede lydighed over for Gud, og er overbevidst om sin urokkelighed i troen i begyndelsen af romanen, går han i slutningen af den med en nagende tvivl i hjertet og stiller spørgsmålet: Hvad er det for en Gud, der kan kræeve sådan noget?. For Aappaluttoq sker lige det modsatte: han kæmper længe med at skulle ofre Paapa, som følge af ofringen oplever han en dyb kierkegaardsk fortvivlelse, men i lyset af de patristiske skrifter, hvor ofringen af sønnen er et billede på Guds ofring af Kristus, kan læseren genkende frelseshistoriske aspekter i historien. Appaluttoq ofrer sin søn, ved dette får han et nyt liv (og renser samtidig også Frederik Christian for hans synder). På den måde når han frem til en forsoning, som gør ham i stand til at acceptere noget højere og tage sin opgave på sig. Han bliver Guds udvalgte, en rigtig Abraham, Abraham Grønlænder, som er kaldet til at lede sit folk ${ }^{9}$. Men denne indsigt kommer først senere. De flere gange gentagne ord fra romanens begyndelse "evigt ejes kun det tabte" (15) får først mening i slutningen af historien.

Ud over Abraham påvirker også Jobs figur hans selvbillede. I begyndelsen af romanen opfatter han sig selv som Job, der har mistet alt (hans kone er død og for at redde sin søns liv, måtte han afgive ham til præsten), men i slutningen af romanen ligger vægten på, at han har fået alt tilbage. I Aappaluttoqs selvforståelse fremhæves offerhandlingens aktive aspekt (sacrifice), hvor han ofrer Frederik Christian i håbet om at få Paapa tilbage. Efter deres møde på havet er han nødt til at erkende, at sønnen er blevet for dansk og for "kristen" til at kunne forlade sit nye liv i Egedes hus og vende tilbage til det gamle hos ham. Og når han således også bliver klar over, at han ikke kan redde ham ud af et moralsk og fysisk forfald, må han indse, at den eneste måde at rense ham på er at dræbe ham. I hans offerhandling blandes en egoistisk, hedensk-menneskelig opfattelse med et kristent aspekt. Hvis han ikke kan få sin søn tilbage, skal Egede heller ikke have ham. ${ }^{10}$ Aappaluttoq er endnu ikke i stand til endegyldigt at give afkald på Frederik Christian, og overlade ham til præsten, til Egedes kristendom og på den måde også til Gud. Hans rituelle handling har ikke noget ophøjet mål, i ofringen af sønnen er der ikke noget sakralt, som kunne gøre det muligt at genoprette hans tilintetgjorte verdensorden. Ved den kan han ikke genvinde sin mistede indre balance. Drabet er meget konkret og på det tidspunkt, hvor det sker, kan det ikke være meningsgivende, det er kun et tilfældigt udtryk for livsvilkårenes ukontrollerbarhed og usikkerhed. Her kan man igen henvise til Kierkegaards skrift og med rette sammenligne Appaluttoq med den mand, som har misforstået Abrahams historie og efter at have hørt en søndagsprædiken om ham, gik hjem for at handle på samme måde ${ }^{11}$.

i stand til at genopvække hans søn. Det var nok derfor, han var så urokkelig i sin tro. For yderligere uddybning af emnet henvises til Finn Damgaards analyse fra 2007.

9 "Herren sagde til Abraham: "Forlad dit land og din slægt og din fars hus, og drag til det land, jeg vil vise dig. Jeg vil gøre dig til et stort folk og velsigne dig. Jeg vil gøre dit navn stort, og du skal være en velsignelse." 1 Mos 12; 1-3.

10 Denne tankegang afspejles i Appaluttoqs verbale (15) og fysiske dueller (369) med Egede.

11 "Fortællingen om Abraham har nu den mærkelige Egenskab, at den altid bliver herlig, hvor fattigt man end forstaaer den [...] Man taler til Abrahams Ære, men hvorledes? Man giver det Hele et gan- 
Appaluttoqs forståelse af historien, lige som hans forståelse af kristendommen er konkret, han er endnu ikke i stand til at fatte det billedlige.

For Appaluttoq får Frederik Christians offerdød først mening, når han opgiver at kæmpe mod Egede, deres konflikt vendes til forsoning og åndemaneren endeligt kan give slip på sin søn. Det er først der, alt falder på plads for ham, og han kan få fred. "Han er død. Det var nødvendigt" (469), siger han til Egedes døende kone. Ofringen fører på den måde til genfødelse, bliver meningsskabende og resulterer ikke kun i en individuel genopstandelse, men bidrager også, ved at konvertere en moralsk overlegenhed til ansvarsfølelse og ydmyghed over for sit folk, til en kollektiv oprejsning.

\section{Fædre og sønner}

Forholdet mellem den danske missionær, Hans Egede og den grønlandske åndemander, Aappaluttoq er en overbevisende illustration af mødet mellem kolonisatorer og koloniserede og bliver udfoldet gennem skildringen af deres indædte kamp for den sidstes søn Paapa. Egede tager Aappaluttoqs syge søn til sig, redder hans liv og ser sig selv berettiget til at berøve ham hans grønlandske identitet og tilbyde ham en dansk i stedet, hvilket påtvinger drengen en dobbeltidentitet, der til sidst afløses af rodløshed. Lige meget hvor han nu færdes, konfronteres han med sin sårende anderledeshed. Han er både et fremmedelement i Egedes hus, hvor han - på trods af præstens faderlige følelser for ham - ikke engang kan gøre sig fortjent til at blive slået, og blandt de indfødte, som gør grin med hans danske påklædning og den mærkelige trekantede hat. Han er fanget mellem sine to fædre. Han ligner den sæl, han skyder og hans far tager fra ham i deres symbolske duel på havet ${ }^{12}$. Efter mødet med danskheden og opdragelsen i kristendommen kan han ikke længere finde sin plads i de grøndlandske omgivelser, hvilket fører til et faderopgør med Aappaluttoq. Opgøret falder ud til fordel for præsten, men Frederik Christian hører aldrig op med at tvivle på sin identitet:

Jeg duer ikke til at leve i det her land. Hvorfor har Gud ladet mig blive født her? Hvad er meningen med det? Kan du da ikke se at jeg er en fremmed? [...] Men jeg er ikke hedning. Jeg er Frederik Christian, ikke Paapa. Jeg er kristen. Er jeg ikke? (Leine 2018, 376).

Selv om Egede behandler ham med de bedste intentioner og har store planer med ham i missionen, kommer han til kort og bliver til en moralsk og menneskeligt nedbrudt figur. Paapa er endegyldigt tabt, både for sin far og sit folk, lige som Frederik Christian er det for Egede og den danske mission. På den måde virker hans endeligt helt naturligt: Aappaluttoq ofrer ham, fordi han endnu ikke kan acceptere, at han har mistet ham til præsten og fordi det er den eneste måde at rense sønnens navn på og sætte en stopper for hans utugt og udskejelser. Hans gerning konfronterer Egede med, at han også skal give slip på

ske almindeligt Udtryk: »det var det Store, at han elskede Gud saaledes, at han vilde offre ham det Bedste.« [...] Man taler da, i Talens løb vexle de tvende udtryk: Isak og det Bedste. Alt gaar ypperligt. Traf det sig imidlertid saa, at der iblandt Tilhørerne var en Mand, der leed af Søvnløshed, da ligger den forfærdeligste, den dybeste, tragiske og comiske Misforstaaelse meget nær. Han gik hjem, han vilde gjøre ligesom Abraham; thi sønnen er jo det Beste." (Kierkegaard 124).

12 "[...] den kan ikke blive fri. Den er fordømt. Den er et levende væsen der skal dø" (Leine 2018, 375). 
drengen, men præsten er endnu ikke klar til det, da det også betyder, at han er nødt til at erkende, at hans planer med Frederik Christian også falder til jorden.

Det er ikke kun Appaluttoq, som ser Abrahams offer gentage sig i sin gerning. Også Egede opfatter sig selv som Abraham, men i hans forståelse er det først pagten med Gud, der dominerer. I Frederik Christian får han en søn, en åndelig søn, der skal hjælpe ham $i$ at fuldføre sin opgave at kristne Grønlands hedenske befolkning. Det gammeltestamentlige billede af løftets $s ø n^{13}$ forbindes i romanen med Jesu skikkelse ${ }^{14}$ og på den måde rettes opmærksomheden på ofringsperspektivet. Det er ikke en konkret offergerning, som i tilfælde af Appaluttoq. Egede skal give afkald på sine planer med drengen, som hans kærlighed til Frederik Christian symboliserer. Men hvad er det for nogen planer? Er de virkelig Guds befaling eller kun Egedes fikse ide? Han er i hvert fald ikke stærk nok til at give slip på dem, mens drengen er i live. Det er nødvendigt, at han mister Frederik Christian fysisk, fordi kærligheden til ham og hans selvpålagte opgave er stærkere end hans kærlighed til Gud.

Når læseren konfronteres med ungens skæbne, som senere gentages i en anden grønlandsk drengs, Carls historie, er det uundgåeligt at stille sprøgsmålstegn ved danskernes missionsforsøg. Hvorfor skulle grønlænderne overtage danskernes i og for sig problematiske livsform og tro, hvis det virker ødelæggende for dem på alle livets områder? ${ }^{15}$

Leine præsenterer os også for en modsatrettet udvikling i mødet mellem de to kulturer. Visse personer legitimeres ved deres integrationsmuligheder i de indfødtes fællesskab, hvor der kan skelnes mellem forskellige former for integration. Egedes kone, Gertrud bliver ikke en del af det grønlandske fællesskab, men som udenforstående karakteriseres hun af accept. Hun har et rationelt syn på grønlænderne, deres hedenskab opfatter hun ikke som en virkelig religion, men "bare en måde at forholde sig til den krævende natur og et uforudsigeligt klima på” (400). Hendes modpol er doktor Kieding, hvis ændrede attitude og forsøg på at indordne sig i det autentiske naturmiljø i romanens slutning viser sig at være en god måde at blive forsonet med omstændighederne og finde den indre balance på. Johan, den tidligere tugthusfange og hans kone, Sise tilpasser sig tilsyneladende de grønlandske livsvilkår, klarer sig ved at overtage meget fra de indfødtes livsform, men ikke noget fra deres hedenske ritualer. På den måde kan de ikke integreres i det grønlandske samfund, de er snarere med til en fredelig udbredelse af den europæiske civilisation, når de tilslutter sig den herrnhutistiske menighed.

I forbindelse med integrationsspørgsmålet er det igen sønnerne, der indtager den mest fremtrædende plads i historien. Egede og Gertruds ældste søn, Poul går traditionerne tro

13 Se 1 Mos 21, 1-8.

14 "Du lignede grangiveligt Frelseren selv da han blev taget ned fra korset. [...] jeg følte at det var Herren selv der havde overgivet dig i min varetægt, at du var en slags nådegave fra Ham, men også en gave fra landet, fra Grønland, og et tegn til mig om at jeg skulle blive her i landet og føre de vilde til Jesus, og det skulle du hjælpe mig med. For mig var det en pagt jeg indgik med Herren. [...] og lige meget hvad der sker med dig, vil jeg være din jordiske far" (Leine 2018, 372).

15 J.B. Pedersen argumenterer i sin artikel Populisten Leine for at kulturmøder generelt afføder positiv udvikling, men i Rød mand/sort mand leder han forgæves efter muligheden for en gensidig befrugtning mellem de to kulturer. Han hævder, at „den depraverede danske og den ædle vilde er modpoler, og det møde fører uundgåeligt til den ægte og oprindelige kulturs undergang”. Pedersen forenkler Leines udlægning af sameksistensen af det grønlandske og det danske, og beskylder forfatteren for at være populist og forkynde Grønlands uafhængighed som en mulig løsning på de aktuelle problemer. Men Leine tegner et meget mere nuanceret billede. 
i sin fars fodspor, han påtager sig ansvaret for fortsættelsen af den grønlandske mission, men selv om han ikke er fremmed for landets kultur, repræsenterer han ikke et reelt alternativ med hensyn til dets fremtid. Han bliver heller ikke i landet, men varetager opgaverne i forbindelse med missionen fra København.

Matthias Jochumsen ankommer til Grønland med store forhåbninger både for sig selv og sin søn Knud ${ }^{16}$, som han i lang tid har haft en del konflikter med. Han forsøger konstant at rette op på ham, men opnår ikke noget ud over afvisning, snyd og bedrag. Men når han ser, at Grønland har en positiv virkning på sønnen, begynder han at tro på fremtiden. Men han bliver skuffet i sine forventninger og efter Frederik Christians død overlader han Knud til Egede, som tager ham under sine vinger og tilbyder ham at blive i kolonien. Når Knud fortæller sin far sin beslutning om ikke at tage hjem, giver han for første gang slip på sin søn, men afskeden bliver først endegyldig, når Knud for altid træder ud af hans liv og forsvinder i fjeldene for at tilslutte sig Aappaluttoq. Ved at vælge den grønlandske levevis gennemfører han sit opgør mod farens dominans og gør sig både fri for de belastende familiebindinger og sin danske identitet.

Ingen af de i romanen præsenterede strategier med hensyn til integration kan opfylde deres formål på nær en, der kan åbne for nye muligheder. Man kan måske med rette hævde, at det er Egedes yngste søn, Niels, der kan bidrage til forsoningen mellem koloniherrer og koloniserede. Han er af natur tiltrukket af den grønlandske livsform. Han færdes hjemmevant i naturen og blandt de indfødte og lærer også deres sprog, hvilket sikrer ham adgang til en dybere indsigt i deres kultur og religion. På det tidspunkt, hvor han bryder med sin far, forlader kolonien, får sig en grønlandsk samleverske og slutter sig til de vildes jagtselskab, snakker han om sig selv som grønlænder:

Nuuk, som vi [min fremhævelse] grønlændere kalder Godthåbshalvøen, har altid været en poststation [...] Det var lige tiden til efterårsjagten nu, gik det op for mig, og jeg bestemte mig for at gå ind i landet for at se om jeg kunne finde et jagtselskab, og så ville jeg slutte mig til dem og jage ligesom dem med harpun og bue. Jeg kommer alligevel bedre ud af det med dem end med det danske mandskab, for ikke at tale om min far, den djævel, den satan, Lucifer, Belzebub (Leine 2018, 353-354).

Det at han i så høj grad er tiltrukket af den grønlandske kultur og levevis, forklarer også den manglende forståelse mellem ham og hans far, som gerne vil tvinge ham ind i rollen som den økonomiske leder af kolonien, hvilket han på grund af sin naturlige tilbøjelighed afviser. Opholdet blandt de indfødte hjælper ham med bedre at forstå sig selv og finde sin vej og bidrager dermed også til at konflikten med faren løses. Samtidigt bliver Egede også bevidst om sin forkerte indstilling til sin søn. Denne erkendelse gør det muligt for ham, at han ofrer sin søn, eller rettere ofrer sin drøm om ham. I deres tilfælde er det først Niels, der genkender Abraham og Isaks historie i deres forhold, og ser sig selv som offer i den passive forstand (victim), hvilket for ham er ensbetydende med svigt, mens præsten nægter at finde forbindelse til den bibelske fortælling, men alligevel bliver mere åben for sønnens ønsker og livsform. I perioden, hvor Niels opholder sig hos de indfødte, træder Aappaluttoq i farens sted, han oplærer ham bl.a. i jagt og virker i en kort

16 "Jeg så Grønland som fremtidens land, mulighedernes land, en ny verden hvor kongen kunne rette op på rigets skrantende finanser, og jeg på min families navn og ære." (Leine 2018, 388) 
tid som hans vejviser for på den ene side at finde en erstatning for Paapa og på den anden side at hævne sig på præsten ved at støtte sønnens oprør mod ham. Ved til sidst at svigte ham bidrager han også til at Niels finder svar på sine spørgsmål: "Kan man både være en Egede og en vildmand? [...] Kan man være både grønlænder og dansker?" (357) og vender tilbage til sine. Selv om Niels' opbrud fra koloniens liv og integration i de indfødtes samfund kun er midlertidigt, fremmer det i sidste instans forståelsen kulturerne imellem på trods af, at han bliver bevidst om visse uovervindelige modsætninger. Som den økonomiske leder af kolonien bliver han i landet, men læseren kan endnu ikke vide, om han indfrier de forventninger, der stilles til ham med hensyn til koloniseringsprocessen.

Generationskonfliktens og ofringsmotivets bearbejdelser i udlægningen af fader-søn-konflikterne falder smukt i tråd med Kim Leines fortolkning af historien om Abraham og Isak, som han redegør for i en artikel i Kristeligt Dagblad:

For mig handler historien om Abraham og Isak ikke om troens natur, ikke om total lydighed mod Gud, men om at vi alle er nødt til før eller senere at ofre vores egne børn (Leine 2020).

Hvilket for Aappaluttoqs vedkommende manifesterer sig i en konkret handling: han dræber sit barn. Denne handling afspejler også den meget konkrete måde at opfatte Biblens ord på (en konkrethed, der generelt præger de indfødtes forhold til de bibelske fortællinger). Først senere erkender han at det, at give afkald ikke er ensbetydende med drab. Når han bliver i stand til at forsone sig med præsten og forstå kristendommens kærlighedsbudskab, kan han i en højere forstand slippe sin søn. Her er det ikke længere den personlige konflikt, kampen om drengen, der bestemmer hans opførsel. I det sidste halvt hallucinerede møde med Egede kan han godt sige "vores søn" til præsten, som gengælder denne gestus ved at snakke om Frederik Christian som hans søn. En gestus, der kan opfattes som et symbolsk afkald på drengen, som han dermed overlader til sin gamle modstander. Det tragiske i deres historie ligger i, at erkendelsen kom for sent og at den bitre had kostede Paapa livet.

Det er dette forsoningens moment som kan sættes i nutidsperspektiv og som stadig lader vente på sig i forholdet mellem Danmark og Grønland. Leines to romaner præsenterer to etapper i grønlændernes kamp for uafhængighed. I Rød mand/sort mand modsætter grønlænderne sig den danske kolonimagt ved at beholde deres egen tro og ikke at acceptere den kristne religion, mens de i Profeterne i Evighedsfjorden finder deres egen vej og på den måde vil løsrive sig fra koloniherrerne. Man kan kun håbe, at den religiøse forsoning i romanens fiktive univers også forudsiger en reel forsoning i nutidens politiske udvikling.

\section{LITTERATUR}

Csúr, Gábor (2020) A történelmi regény alakváltozatai a második ezredforduló utáni skandináv irodalomban. $\mathrm{PhD}$-afhandling, Budapest: ELTE, 2020.

Damgaard, Finn. "Skygger og allegori. Origenes' og Chrysostomos' homilier over Isaks ofring." Patristik 5 (2007): 2-26.

Handesten, Lars. "Det gode og overvældende stof i Kim Leines rå grønlandshistorie er både hans ven og fjende." Kristeligt Dagblad, 2. marts 2018. https://www.kristeligt-dagblad.dk/kultur/kampen-omsjaelene [3. 3. 2021]. 
Hankovszky, Béla. "Az értelmezés kötelezettsége: Ábrahám áldozata." Akéda. Ábrahám és Izsák története az egyházatyák értelmezésében. Ed. Heidl, György, Hankovszky, Béla. Budapest: Kairosz, 2004. 9-30.

Kierkegaard, Søren. Frygt og Bæeven. In Søren Kierkegaards Skrifter 4. København: Gads Forlag, 1998. 97-210.

Leine, Kim. Profeterne i Evighedsfjorden. København: Gyldendal, 2012.

Leine, Kim. Rød mand/sort mand. København: Gyldendal, 2018.

Leine, Kim. "Vi må alle ofre vores børn, som Abraham ofrede Isak." Kristeligt Dagblad, 9. december 2017. http://www.kristeligt-dagblad.dk/debat/vi-maa-alle-ofre-vores-boern-som-abraham-ofrede-isak. [3. 3. 2021].

Nielsen, Mathias. '"Gennem mine årer fosser fjeldenes store elve' - Forestillinger om grønlandskhed hos det grønlandske rockband Sume 1973-1976." Culture and History 5 (2020): 6-22.

Órigenész. "Órigenész nyolcadik homíliája a Teremtés könyvéhez. (Ábrahám felajánlotta fiát, Izsákot)." Vigília, 7 (1998): 484-491.

Pedersen, Jeppe Bredahl. „Populisten Leine.” Weekendavisen, 12. april 2018. http://www.weekendavisen. $\mathrm{dk} / 2018-15 /$ samfund/populisten-leine [1.2. 2020].

Said, Edward/Burgmer, Christoph. "Bevezetés a posztkoloniális diskurzusba." Magyar Lettre International 28 (1998): 24-29.

Said, Edward W. Orientalism. Vintage. 1979.

Thisted, Kirsten. "Imperiets genfærd: Profeterne i Evighedsfjorden og den dansk-grønlandske historieskrivning." Nordlit 35 (2015): 105-121.

\section{Anita Soós}

Eötvös Loránd University Budapest

soos.anita@btk.elte.hu 